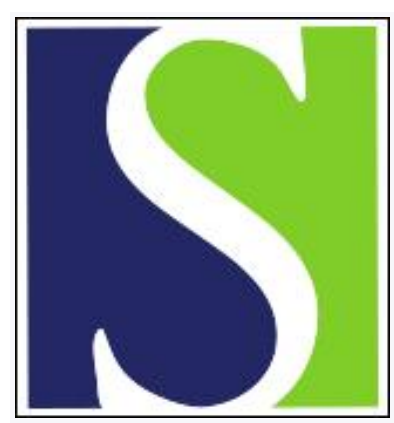

Scand J Work Environ Health 1985;11(4):317-320

https://doi.org/10.5271/sjweh.2217

Issue date: Aug 1985

Biological reactivity of different crystalline forms of titanium dioxide in vitro and in vivo.

by Richards RJ, White LR, Eik-Nes KB

This article in PubMed: www.ncbi.nlm.nih.gov/pubmed/4059894

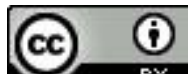




\title{
Biological reactivity of different crystalline forms of titanium dioxide in vitro and in vivo
}

\author{
by Roy J Richards, PhD, ${ }^{1}$ Linda R White, PhD, ${ }^{2}$ Kristen B Eik-Nes, MD ${ }^{2}$ \\ RICHARDS RJ, WHITE LR, EIK-NES KB. Biological reactivity of different crystalline forms of titanium \\ dioxide in vitro and in vivo. Scand $J$ Work Environ Health 11 (1985) 317-320. The biological reactivity \\ of two crystalline forms of titanium dioxide, rutile and anatase, has been compared in in vitro and in \\ vivo assays. Rutile and anatase induced similar effects, and both had a very low biological activity in \\ comparison to $\alpha$-quartz. Rutile samples containing trace amounts of nickel or chromium had an activity \\ similar to that of pure rutile.
}

Key terms: bovine alveolar macrophages, intratracheal instillation, rat lung.

Titanium dioxide $\left(\mathrm{TiO}_{2}\right)$ is generally considered to be biologically inert and is therefore often used as a negative control in mineral studies. However, this substance occurs in several crystalline forms, the two most common being rutile and anatase.

The production of titanium dioxide pigment creates a dusty work environment and can lead to heavy dust deposition in the lungs of some workers. Several studies have been carried out to ascertain the human pulmonary response to titanium dioxide $(1,3,6,9$, $13,15)$, which is generally considered fairly inert, but there is some conflict of results. In addition the crystalline form of deposited titanium dioxide has rarely been determined. Two reports with such a determination $(9,13)$ leave little doubt that rutile titanium dioxide is inert even after massive deposition. However, doubt has been expressed (20) as to whether anatase is as inert as rutile. This possibility again raises doubts as to whether the pulmonary response found in some studies $(3,6)$ was due to the presence of other substances used in the manufacture of titanium dioxide pigments (a possibility considered by the authors) or to the presence of other, less inert, crystalline forms of titanium dioxide, as tentatively suggested by others $(9,13)$. Certainly industrial titanium dioxide pigments (including some coated with silica) did not exert appreciable toxicity towards mouse peritoneal macrophages (8). However, alteration of the chemical properties of a dust may change its biological potency. Thus Desai (2) demonstrated that titanium dioxide particles containing small amounts of nickel or chromium pro-

\footnotetext{
1 Department of Biochemistry, University College, Cardiff, United Kingdom.

2 Institute of Biophysics, Norwegian Institute of Technology, University of Trondheim, N-7034 Trondheim-NTH, Norway.
}

Reprint requests to: Dr RJ Richards, Department of Biochemistry, University College, PO Box 78, Cardiff CF1 1XL, Wales, UK. duced greater hemolysis of erythrocytes than control samples of titanium dioxide.

To clarify this situation, we have compared rutile and anatase activity against bovine alveolar macrophages in vitro and also after instillation into rat lung in vivo. Rutile samples containing trace amounts of nickel or chromium were also studied in these assays to determine whether they would alter the activity of rutile. An overall comparison of the titanium dioxide samples was made with the effects produced by $\alpha$-quartz, a mineral of high biological activity.

\section{Materials and methods}

\section{Titanium dioxide samples}

The samples of rutile, rutile plus nickel (Ni), and rutile plus chromium $(\mathrm{Cr})$ were gifts from Dr R Breakspeare, Department of Chemistry, University College, Cardiff. The rutile plus nickel sample contained $1058 \mathrm{ppm}$ of nickel and the rutile plus chromium sample contained $759 \mathrm{ppm}$ of chromium, as determined by atomic absorption spectrometry (PerkinElmer model 503). Water-soluble hexavalent chromium $(\mathrm{Cr}$ VI) was not detected in the latter sample by the S-diphenylcarbazide method (14). Anatase was purchased from British Drug Houses, Poole, Dorset, United Kingdom. The samples of anatase and rutile used in the experiments were obtained by water sedimentation (5) (particle size $<3 \mu \mathrm{m}$ ), heat-sterilized at $140^{\circ} \mathrm{C}$ for $2 \mathrm{~h}$, and dispersed in isotonic saline by ultrasonication immediately prior to use. DQ12 $\alpha$-quartz was a kind gift from Dr C Hardy, Huntingdon Research Centre, United Kingdom.

\section{Alveolar macrophages}

The alveolar macrophages were obtained from bovine lungs by lavage (7) within $1 \mathrm{~h}$ of slaughter. Populations containing greater than $90 \%$ monocytes 
were washed three times in sterile sodium chloride $(0.15 \mathrm{~mol} / \mathrm{l})$ containing penicillin $(100 \mathrm{units} / \mathrm{ml})$ and streptomycin $(100 \mu \mathrm{g} / \mathrm{ml})$. The cells were suspended in Eagles MEM (minimum essential medium) supplemented with $10 \%$ heat-inactivated newborn calf serum (Gibco Europe, Scotland), and $2 \times 10^{6}$ cells were seeded into plastic petri dishes (Costar, United States), $5-\mathrm{cm}$ in diameter, containing $5 \mathrm{ml}$ of medium and incubated in $5 \%$ carbon dioxide $/ 95 \%$ air at pH 7.2. Nonadherent cells were removed by the replacement of the culture medium after $4 \mathrm{~h}$, and suspensions $(0.2 \mathrm{ml})$ of the dust samples were incubated with these cells for a further $24 \mathrm{~h}$. After this time the cell numbers were counted, and their viability was assessed by the exclusion of trypan blue.

\section{Intratracheal instillation}

Male Wistar rats two months of age and weighing approximately $250 \mathrm{~g}$ (Norwegian Institute of Public
Health, Oslo) were anesthetized with halothane and instilled with 5-mg quantities of the dust samples suspended in isotonic saline (12). Control animals received saline only. At one and four weeks after the instillation the animals from each group $(\mathrm{N}=4)$ were killed, and the body weight recorded. Each lung was lavaged, blotted dry to remove excess fluid, and then weighed and frozen $\left(-20^{\circ} \mathrm{C}\right)$ prior to the analysis. The lavage fluid was fractionated to obtain the free cells, alveolar surface protein, and pulmonary surfactant (18). Differential counts on Giemsa-stained smears of free cells and biochemical assays for the enzymes, deoxyribonucleic acid, and protein were all performed as described previously (17). The results given in table 2 in the Results section represent the mean value of each parameter studied in four rats. The variation within any individual group of four animals was less than $20 \%$ for lung and body weights, and for the free cell counts less than $30 \%$ (control and rutile), $<40 \%$ (anatase and rutile plus

Table 1. Effect of titanium dioxide $\left(\mathrm{TiO}_{2}\right)$ samples on the viability of bovine alveolar macrophages after $24 \mathrm{~h}$ in culture. ${ }^{a}$

\begin{tabular}{|c|c|c|c|c|c|c|c|c|c|c|}
\hline \multirow{3}{*}{$\begin{array}{l}\text { Concentration } \\
(\mathrm{mg} / \mathrm{l})\end{array}$} & \multicolumn{8}{|c|}{ Titanium dioxide } & & \\
\hline & \multicolumn{2}{|c|}{ Anatase } & \multicolumn{2}{|c|}{ Rutile } & \multicolumn{2}{|c|}{ Rutile + nickel } & \multicolumn{2}{|c|}{$\begin{array}{l}\text { Rutile + } \\
\text { chromium }\end{array}$} & \multicolumn{2}{|c|}{$\alpha$-Quartz } \\
\hline & Mean & SD & Mean & $\mathrm{SD}$ & Mean & SD & Mean & SD & & \\
\hline $\begin{array}{r}\overline{40} \\
100\end{array}$ & $\begin{array}{l}88 \\
89 \\
83\end{array}$ & $\begin{array}{l}1 \\
1 \\
2\end{array}$ & $\begin{array}{l}88 \\
85 \\
86\end{array}$ & $\begin{array}{l}1 \\
3 \\
4\end{array}$ & $\begin{array}{l}88 \\
84 \\
88\end{array}$ & $\begin{array}{l}1 \\
3 \\
4\end{array}$ & $\begin{array}{l}88 \\
80 \\
83\end{array}$ & $\begin{array}{l}1 \\
2 \\
3\end{array}$ & $\begin{array}{l}90 \\
55 \\
40\end{array}$ & $\begin{array}{r}2 \\
6 \\
14\end{array}$ \\
\hline
\end{tabular}

a Results are expressed as the percentage of cells excluding trypan blue dye and show the mean and standard deviation of three experiments. Cells exposed to $\mathrm{TiO}_{2}$ were $>95 \%$ phagocytic.

Table 2. Effects of titanium dioxide samples and $\alpha$-quartz on rat lung in vivo four weeks after instillation. ${ }^{a}$ ( $N R=$ not recorded)

\begin{tabular}{|c|c|c|c|c|c|c|}
\hline Parameter & $\begin{array}{l}\text { Control } \\
\text { (saline only) }\end{array}$ & $\begin{array}{l}\text { Anatase } \\
(5 \mathrm{mg})\end{array}$ & $\begin{array}{l}\text { Rutile } \\
(5 \mathrm{mg})\end{array}$ & $\begin{array}{l}\text { Rutile + nickel } \\
\quad(5 \mathrm{mg})\end{array}$ & $\begin{array}{l}\text { Rutile + } \\
\text { chromium } \\
(5 \mathrm{mg})\end{array}$ & $\begin{array}{c}\alpha \text {-Quartz } \\
\text { (5 mg) }\end{array}$ \\
\hline $\begin{array}{l}\text { Wet lung weight: } \\
\text { body weight } \times 10^{4}\end{array}$ & 46 & 46 & 45 & 46 & 48 & 76 \\
\hline Wet lung weight $(g)$ & 1.37 & 1.37 & 1.39 & 1.48 & 1.44 & 3.29 \\
\hline $\begin{array}{l}\text { Lung deoxyribonucleic acid } \\
\text { (mg/g lung) }\end{array}$ & 5.7 & 6.8 & 6.1 & 5.7 & 6.0 & 4.5 \\
\hline Lung protein (mg/g lung) & 96 & 95 & 87 & 93 & 93 & 100 \\
\hline $\begin{array}{l}\text { Lung acid ribonuclease } \\
\text { (units } \cdot g \text { lung }{ }^{-1} \cdot h^{-1} \text { ) }\end{array}$ & 111 & 107 & 114 & 108 & 128 & 155 \\
\hline $\begin{array}{l}\text { Lung acid protease } \\
\text { (units } \cdot g \text { lung }{ }^{-1} \cdot \mathrm{h}^{-1} \text { ) }\end{array}$ & 14.9 & 14.9 & 14.9 & 20.5 & 17.7 & 23.5 \\
\hline $\begin{array}{l}\text { Pulmonary surfactant } \\
\text { (mg/g lung) }\end{array}$ & 0.44 & 0.61 & 0.68 & 0.57 & 0.44 & 4.65 \\
\hline $\begin{array}{l}\text { Number of free cells/g } \\
\text { lung } \times 10^{-6}\end{array}$ & 8.5 & 8.2 & 7.7 & 7.0 & 7.1 & 56.5 \\
\hline $\begin{array}{l}\text { Number of } \\
\text { polymorphonuclear } \\
\text { leucocytes/g lung } \times 10^{-6}\end{array}$ & 0.04 & 0.66 & 0.15 & 0.29 & 0.53 & NR \\
\hline $\begin{array}{l}\text { Percentage of dust-bearing } \\
\text { alveolar macrophages of } \\
\text { total alveolar macrophages }\end{array}$ & 0.1 & 51.5 & 35.6 & 36.2 & 52.2 & NR \\
\hline $\begin{array}{l}\text { Free cell acid ribonuclease } \\
\text { (units } \cdot 10^{6} \text { cells }{ }^{-1} \cdot h^{-1} \text { ) }\end{array}$ & 0.33 & 0.52 & 0.39 & 0.43 & 0.66 & 0.47 \\
\hline $\begin{array}{l}\text { Free cell acid protease } \\
\text { (units } 10^{6} \text { cells }{ }^{-1} \cdot h^{-1} \text { ) }\end{array}$ & 0.14 & 0.19 & 0.15 & 0.18 & 0.20 & 0.18 \\
\hline
\end{tabular}

a Values are the means of four rats. (See the text for limits of variation.) 
chromium), and $<60 \%$ (rutile plus nickel). All the biochemical assays, performed in triplicate, were within $\pm 10 \%$ for the pooled samples of each group.

\section{Results}

The reaction of the titanium dioxide samples with bovine alveolar macrophages is shown in table 1 . No significant cytotoxic reaction was detected in any of the cultures treated with any titanium dioxide sample, even though most of the cells $(>95 \%)$ were actively phagocytic. By comparison, $\alpha$-quartz was considerably more toxic towards the macrophages in this culture system, with significant loss of viability in comparison to control cultures at concentrations over $40 \mathrm{mg} / \mathrm{l}$. At the corresponding highest concentration of titanium dioxide used $(100 \mathrm{mg} / \mathrm{l})$, quartz-exposed cells not only showed a considerable loss of viability (table 1), but also became morphologically misshapen and prone to autolysis. This occurrence contrasted with the titanium dioxide-exposed cultures, which maintained their morphology even after the ingestion of large numbers of titanium dioxide particles.

There were no major differences in the reaction to titanium dioxide compounds in the rat lung at one and four weeks after instillation, except where indicated, and therefore only the four-week data are given (table 2). The titanium dioxide samples produced little or no effect on any of the lung tissue parameters measured or any alteration in the amount of pulmonary surfactant. Some changes, however, were found in the free cell population in that both anatase and the rutile plus chromium samples elevated the total cell population by $80 \%$ at one week after instillation (data not shown). This effect did not persist, and at four weeks both the controls and samples from rats treated with titanium dioxide had similar numbers of free cells removable by lavage. All of the titanium dioxide samples induced an influx of polymorphonuclear leucocytes (PMN) into the lung one week after instillation. This effect was still noted at four weeks (table 2) although it was less pronounced for the rutile sample. Many of the alveolar macrophages were laden with dust at four weeks, and this occurrence may in turn account for the increase in the activity of the free cell hydrolytic enzymes. The most marked changes were found with acid ribonuclease, which, four weeks after the instillation, had increased by $57 \%$ in the anataseexposed cells and by $100 \%$ in cells exposed to rutile plus chromium.

However, all the changes induced by the titanium dioxide samples were minimal compared to those induced by a corresponding 5-mg instillation of $\alpha$-quartz (table 2). At the lung surface, the number of free cells and the amount of pulmonary surfactant were considerably increased, and substantial increases were recorded in all parameters measured in lung tissue (lung weight, total lung deoxyribonucleic acid, protein, and hydrolytic enzymes).

\section{Discussion}

The bovine alveolar macrophages were able to engulf large amounts of all of the titanium dioxide samples without significant loss of viability over $24 \mathrm{~h}$. This result contrasts with the effects produced by $\alpha$-quartz (table 1) and also other toxic dusts such as chrysotile asbestos and welding-fume particles given to these cells at much lower doses (19).

The short-term instillation studies with rats show that none of the titanium dioxide samples altered the biochemical parameters in the lavaged lung tissue and therefore indicates that their reactivity was confined to the lung surface. Even then, the samples produced only a minimal inflammatory response and no alteration in the level of the pulmonary surfactant. The elevation of the lysosomal enzyme acid ribonuclease in the free cell population of some samples may simply reflect a nonspecific response to dust phagocytosis. The data in table 2 provide a sharp contrast between the effects of the titanium dioxide samples and those of a toxic dust such as $\alpha$-quartz, the results from the pulmonary surface being in agreement with similar studies showing excessive polymorphonuclear leucocyte infiltration of the lung (16) and pulmonary surfactant elevation, a condition that is progressive (10).

The general conclusion from these results is that there is no significant difference between the biological reactivity of rutile and anatase in these assay systems. Even though we have only used short-term studies, the results give no indication that long-term effects are to be expected. Another paper has also just been published (4) which compares the reactivity of well-characterized samples of rutile and anatase after the measurement of lung clearance following inhalation. Clearance was identical for the two samples over a four-month period, and histologically the lung tissue was found to be normal, apart from a macrophage response. The free cell population obtained by lavage $24 \mathrm{~h}$ after instillation of the samples was also similar in both cases. The authors thereby also concluded that there is no difference in activity between rutile and anatase.

Different crystalline forms of titanium dioxide are therefore probably not responsible for the pulmonary effects observed in some human studies $(3,5)$. The addition of traces of nickel or chromium to rutile produced no significant changes in activity in comparison to rutile alone. Data on the possible toxicity of anatase (20) or rutile plus nickel or chromium (2) were all obtained in the hemolysis test. Our results are therefore additional evidence that hemolysis is not a good measure of mineral biological activity (11). Since all the titanium dioxide samples investigated give consistent negative results in the systems employed, it 
seems reasonable to consider them to have very low and similar biological reactivity.

\section{Acknowledgments}

The authors wish to thank the Royal Norwegian Council for Scientific and Industrial Research (NTNF) for its financial support.

\section{References}

1. Daum S, Anderson HA, Lilis R, Lorimer WV, Fishbein SA, Miller A, Selikoff IJ. Pulmonary changes among titanium workers. Proc R Soc Med 70 (1977) 31-32.

2. Desai R. Biochemical studies on the interaction between industrial dust materials, lung cells and cellular components. University of Wales, Cardiff 1976. (Doctoral dissertation).

3. Elo R, Määttä K, Uksila E, Arstila AU. Pulmonary deposits of titanium dioxide in man. Arch Pathol 94 (1972) 417-424.

4. Ferin J, Oberdörster G. Biological effects and toxicity assessment of titanium dioxides: Anatase and rutile. Am Ind Hyg Assoc J 46 (1985) 69-72.

5. Hunt J, Pooley FD, Richards RJ. Biological reactivity of calcium silicate composites - In vitro studies. Environ Res 26 (1981) 51-68.

6. Määttä K, Arstila AU. Pulmonary deposits of titanium dioxide in cytologic and lung biopsy specimens. Lab Invest 33 (1975) 342-346.

7. Myrvik QN, Leake ES, Fariss B. Studies on pulmonary alveolar macrophages from the normal rabbit: A technique to produce them in a high state of purity. J Immunol 86 (1961) $128-132$.

8. Nuuja IJM, Arstila AU. On the response of mouse peritoneal macrophages to titanium dioxide pigment in vitro. Environ Res 29 (1982) 174-184.

9. Ophus EM, Rode L, Gylseth B, Nicholson DG, Saeed K. Analysis of titanium pigments in human lung tissue. Scand J Work Environ Health 5 (1979) 290296.
10. Richards RJ, Curtis CG. Biochemical and cellular mechanisms of dust-induced lung fibrosis. Environ Health Perspect 55 (1984) 393-416.

11. Richards RJ, George G, Hunt J, Tetley TD. The relationship between the haemolytic potential of certain particulates and their reactivity at the lung surface in vivo. In: Brown RC, Gormley IP, Chamberlain $\mathrm{M}$, Davies $R$, ed. The in vitro effects of mineral dusts. Academic Press, London 1980, pp 323-332.

12. Richards RJ, Tetley TD, Hunt $\mathbf{J}$. The biological reactivity of calcium silicate composites: In vivo studies. Environ Res 26 (1981) 243-257.

13. Rode LE, Ophus EM, Gylseth B. Massive pulmonary deposition of rutile after titanium dioxide exposure. Acta Pathol Microbiol Scand Sect A 89 (1981) 455461.

14. Saltzman BE. Microdetermination of chromium with diphenylcarbazide by permanganate oxidation. Anal Chem 24 (1952) 1016-1020.

15. Schmitz-Moorman $P$, Horlein $H$, Hanefeld F. Lungeveränderung bei titandioxydstaubexposition. Beitr Silikose Forsch (Pneumokoniose) 80 (1964) 1-17.

16. Sykes SE, Morgan A, Evans JC, Evans N, Holmes A, Moores SR. Use of an in vivo test system to investigate the acute and sub-acute responses of the rat lung to mineral dusts. Ann Occup Hyg 26 (1982) 593-605.

17. Tetley TD, Hext PM, Richards RJ, McDermott M. Chrysotile-induced asbestosis; changes in the free cell population, pulmonary surfactant and whole lung tissue of rats. Br J Exp Pathol 57 (1976) 505-514.

18. White LR, Hunt J, Tetley TD, Richards RJ. Biochemical and cellular effects of welding fume particles in the rat lung. Ann Occup Hyg 24 (1981) 93-101.

19. White LR, Marthinsen ABL, Jakobsen K, Eik-Nes KB. The response of bovine alveolar macrophages in vitro to welding fumes particles. Environ Health Perspect 51 (1983) $211-215$.

20. Zitting A, Skyttä E. Biological activity of titanium dioxides. Int Arch Occup Environ Health 43 (1979) 93-97.

Received for publication: 16 January 1985 